\title{
Manuscript title: antifungal proteins from moulds: analytical tools and potential application to dry-ripened foods
}

\author{
Josué Delgado $^{1} \cdot$ Rebecca A. Owens $^{2} \cdot$ Sean Doyle $^{2} \cdot$ Miguel A. Asensio $^{1} \cdot$ Félix Núñez $^{1}$
}

Received: 6 May 2016 / Revised: 20 June 2016 / Accepted: 23 June 2016 / Published online: 9 July 2016

(C) Springer-Verlag Berlin Heidelberg 2016

\begin{abstract}
Moulds growing on the surface of dry-ripened foods contribute to their sensory qualities, but some of them are able to produce mycotoxins that pose a hazard to consumers. Small cysteine-rich antifungal proteins (AFPs) from moulds are highly stable to $\mathrm{pH}$ and proteolysis and exhibit a broad inhibition spectrum against filamentous fungi, providing new chances to control hazardous moulds in fermented foods. The analytical tools for characterizing the cellular targets and affected pathways are reviewed. Strategies currently employed to study these mechanisms of action include 'omics' approaches that have come to the forefront in recent years, developing in tandem with genome sequencing of relevant organisms. These techniques contribute to a better understanding of the response of moulds against AFPs, allowing the design of complementary strategies to maximize or overcome the limitations of using AFPs on foods. AFPs alter chitin biosynthesis, and some fungi react inducing cell wall integrity (CWI) pathway. However, moulds able to increase chitin content at the cell wall by increasing proteins in either CWI or calmodulin-calcineurin signalling pathways will resist AFPs. Similarly, AFPs increase the intracellular levels of reactive oxygen species (ROS), and moulds increasing G-protein complex $\beta$ subunit $\mathrm{CpcB}$ and/or enzymes to efficiently produce glutathione may evade apoptosis. Unknown aspects that need to be addressed include the interaction with mycotoxin production by less sensitive toxigenic moulds. However, significant steps have
\end{abstract}

Miguel A. Asensio

masensio@unex.es

1 Food Hygiene and Safety, Institute of Meat Products, University of Extremadura, Cáceres, Spain

2 Department of Biology, Maynooth University, Maynooth, Co. Kildare, Ireland been taken to encourage the use of AFPs in intermediatemoisture foods, particularly for mould-ripened cheese and meat products.

Keywords Antifungal proteins $\cdot$ Food safety $\cdot$ Proteomics . Toxigenic moulds

\section{Introduction}

Ripened foods are spread across the world and represent an important sector in the economy. Fermented foods require the contribution of flavour-producing microorganisms, typically lactic acid bacteria (LAB) and Gram-positive, catalasepositive cocci and yeasts. Filamentous fungi can also contribute to flavour due to their proteolytic and lipolytic activities, particularly in foods of intermediate water activity, such as dry-ripened cheese (Banjara et al. 2015), sausages (Bruna et al. 2003) and hams (Martín et al. 2006).

On the other hand, filamentous fungi can also be responsible for spoilage and health issues in dry-ripened foods. Some moulds have been linked to food allergy after intake of aged mould-coated foods, causing respiratory and digestive disorders in sensitive consumers (Bobolea et al. 2009; Gonzálezde-Olano et al. 2012). Although moulds are not commonly associated with foodborne infections, pneumonitis caused by Aspergillus fumigatus is often an occupational disease in grain or sausage handlers (Swan and Crook 1998; Marvisi et al. 2012). However, the most concerning hazard related to mould presence in foods is mycotoxin production, due to their toxigenic, immunosuppressive, mutagenic and carcinogenic effects (Bezerra da Rocha et al. 2014). Therefore, the control of unwanted moulds in foods is considered a key issue. For this purpose, some efficient physical or chemical treatments, such as modified atmosphere packaging, refrigeration or 
chemical fungicides, are available. However, these treatments are not adequate for mould-ripened foods, since fungal development is essential for their desired sensory characteristics. Moreover, chemical compounds can leave residues, which is against the consumer's demand of residue-free foods. Consequently, biocontrol using natural products could be an alternative to fight against undesirable moulds. Natural antifungal proteins represent an interesting option for biopreservation in foods (Geisen 2000; Delgado et al. 2015a).

Living organisms may defend themselves against fungi by producing antifungal compounds, including proteins. Antifungal proteins (AFPs) are produced by organisms ranging from prokaryotes to plants, insects and mammals (Selitrennikoff 2001). AFPs have been studied as a potential source of new agents to combat opportunistic fungal infections in immunocompromised hosts, as well as fungal plant pathogens. The most extensively studied AFPs are plant defensins (van der Weerden and Anderson 2013), which cause membrane permeabilization in various filamentous fungi (Yan et al. 2015; Zhu et al. 2015) by specifically interacting with host membrane compounds (Vriens et al. 2014).

Moulds can also produce several types of antifungal peptides and proteins, including some cyclic peptides, such as echinocandins (Emri et al. 2013) or aureobasidin A (Liu et al. 2007), enzymes such as glucose oxidase (Leiter et al. 2004) or chitosanases (Rodríguez-Martín et al. 2010b) and defensin-like proteins (Galgóczy et al. 2013). The latter is a group of small, basic and cysteine-rich AFPs that have been the subject of recent research (Table 1).
AFPs produced by non-toxigenic moulds normally present on foods can be a valuable means to improve food safety in intermediate-moisture foods, particularly in uncontrolled mould-ripened meats and dairy products.

The present review focuses on AFPs produced by moulds as well as on the analytical tools for characterizing the effects of AFPs to gain insight into their mechanism of action and to analyze their potential application to dry-ripened foods.

\section{Main characteristics of AFPs}

The main distinguishing features of AFPs and their effect on sensitive moulds have been extensively reviewed elsewhere (Theis and Stahl 2004; Marx 2004; Marx et al. 2008; Hegedüs and Marx 2013). AFP (Campos-Olivas et al. 1995), PAF (Batta et al. 2009) and BP (Seibold et al. 2011) fold into a compact $\beta$-barrel stabilized by disulphide bridges, and it has been assumed that AcAFP, Anafp, NAF and PgAFP also have a similar tertiary structure (Marx 2004; Skouri-Gargouri et al. 2009; Rodríguez-Martín et al. 2010a). This structure confers high stability against adverse biochemical and biophysical conditions, such as low $\mathrm{pH}$, high temperature and some surfactants (Lacadena et al. 1995; Marx 2004; Skouri-Gargouri and Gargouri 2008; Batta et al. 2009; Hajji et al. 2010; Chen et al. 2013; Wen et al. 2014; Delgado et al. 2015a). In addition, AFPs withstand the attack of proteases in vitro (Lacadena et al. 1995; Batta et al. 2009; Delgado et al. 2015a). This raises the possibility of applying AFPs directly onto dry-ripened
Table 1 Antifungal proteins produced by moulds

\begin{tabular}{lllll}
\hline $\begin{array}{l}\text { Antifungal } \\
\text { protein }\end{array}$ & Producer mould & pI & $\begin{array}{l}\text { MW } \\
\text { (Da) }\end{array}$ & Reference \\
\hline AcAFP & Aspergillus clavatus & 9.3 & 5773 & $\begin{array}{c}\text { Skouri-Gargouri and Gargouri } \\
\text { (2008) }\end{array}$ \\
AcAMP & Aspergillus clavatus & 9.06 & 6000 & Hajji et al. (2010) \\
AFP & Aspergillus giganteus & 9.3 & 5800 & Nakaya et al. (1990) \\
AfpB & Penicillium digitatum & - & - & Garrigues et al. (2015) \\
AFP & Aspergillus giganteus & 9.3 & - & Binder et al. (2011) \\
Anafp & Aspergillus niger & 7.14 & 6583 & Gun Lee et al. (1999) \\
BP & Penicillium & 7.2 & 6584 & Seibold et al. (2011) \\
FPAP & Fusarium polyphilaidicum & 9.1 & 6357 & Galgóczy et al. (2013) \\
MAFP1 & Monascus pilosus & 8.3 & 6500 & Tu et al. (2016) \\
NAF & Penicillium nalgiovense & 8.93 & 6300 & Geisen (2000) \\
NFAP & Neosartorya fischeri & 8.93 & 6625 & Kovács et al. (2011) \\
PAF & Penicillium chrysogenum & 8.93 & 6250 & Marx et al. (1995) \\
Pc-Arctin & Penicillium chrysogenum & - & 7000 & Chen et al. (2013) \\
PcPAF & Penicillium citrinum & - & 10,000 & Wen et al. (2014) \\
PgAFP & Penicillium chrysogenum & 9.22 & 6494 & Rodríguez-Martín et al. (2010a) \\
\hline
\end{tabular}


foods to control hazardous moulds, even in foods requiring intensive proteolytic degradation during ripening. These characteristics are seen as an advantage for the use of AFPs in lowacid ripened foods, due to the highly proteolytic microbial population naturally present (Rodríguez et al. 1998; Sousa et al. 2001; Hughes et al. 2002).

According to phylogenetic analysis, AFPs have been classified into three groups, with AFP, PAF, AcAFP, NFAP and FPAP in class A; PgAFP and Anafp in class B; and Pc-Arctin and $\mathrm{BP}$ in class $\mathrm{C}$ (Garrigues et al. 2015).

\section{Spectrum of activity}

AFPs from moulds show a broad inhibition spectrum against filamentous fungi and some zygomycetes, but not against prokaryotes or mammalian cells (Marx 2004; Palicz et al. 2013). Some of the most hazardous moulds, including ochratoxigenic Aspergillus carbonarius, Aspergillus ochraceus, Penicillium nordicum and Penicillium verrucosum; aflatoxigenic Aspergillus flavus and Aspergillus parasiticus; patulinproducers Penicillium expansum and Penicillium griseofulvum; and the pathogenic and allergenic A. fumigatus, are among the species sensitive to AFPs (Kaiserer et al. 2003; Galgóczy et al. 2008; Delgado et al. 2015a). Only AcAMP exhibited inhibitory activity against bacteria (Hajji et al. 2010) and Anafp and BP against yeasts (Gun Lee et al. 1999; Seibold et al. 2011). The generalized lack of activity against bacteria and yeast can be regarded as an advantage for the potential use of AFPs in dryripened foods, given the positive role of these microorganisms on the sensory characteristics of dry-ripened foods.

\section{Analytical tools for characterizing the effects of AFPs}

Deciphering the mechanisms of action and the cellular targets of AFPs continues to be an important objective. Enhanced understanding of the target informs on the activity spectrum of the AFPs and the relative susceptibilities of various organisms. Information can be generated on possible modes of resistance, in addition to guiding the design of combination therapies directed at different targets. Furthermore, potential secondary effects can be elucidated, such as undesirable byproducts of treatment (e.g. increased mycotoxin production). Some of the strategies currently employed to study these mechanisms of action include genomics, fluorescence assays, transcriptomics, proteomics and metabolite analysis (Table 2). Many of these 'omics' approaches have come to the forefront in recent years, developing in tandem with genome sequencing of relevant organisms.

Use of targeted gene deletions or non-functional gene mutations has been employed to verify pathways affected by antifungal agents in sensitive species. Disruption of genes involved in signalling pathways revealed the involvement of G-protein signal transduction in the antifungal activity of PAF from Penicillium chrysogenum and NFAP from Neosartorya fischeri (Leiter et al. 2005; Virágh et al. 2015). Further similarities were found among the targets of AFPs, with direct involvement of the GTPase RhoA ruled out in the case of PAF, NFAP and $\mathrm{AFP}_{\mathrm{NN} 5353}$ from Aspergillus giganteus (Binder et al. 2010b; Binder et al. 2011; Virágh et al. 2015). Genes responsible for conferring resistance to AFPs can also be identified using screens of deletion strains from resistant species. Ouedraogo et al. (2011) revealed a number of genes (chsl, wscl, vps34 and torl) in the AFP-resistant yeast Saccharomyces cerevisiae that give rise to intermediate sensitivity upon deletion. This screen of 100 mutants allowed the authors to ascertain the mechanisms affected in sensitive organisms and directed additional analyses to validate these observations. Recent developments allowing more efficient genetic manipulation of filamentous fungi will enable further large-scale screening using gene disruption libraries (Colot et al. 2006; Park et al. 2011; Liu et al. 2015; Nødvig et al. 2015).

Genome-wide surveys of the pathways affected by antifungal agents have also been achieved through the use of transcriptome analyses. Microarray analysis of the effect of soybean toxin, an AFP, on Candida albicans revealed the altered expression of 61 and 51 genes after 16 and $18 \mathrm{~h}$ of exposure, respectively (Morais et al. 2013). The observed changes in
Table 2 Potential of selected technologies for advancing the characterization of AFPs

\begin{tabular}{|c|c|}
\hline $\begin{array}{l}\text { Selected } \\
\text { technologies }\end{array}$ & Application to antifungal protein characterization \\
\hline $\begin{array}{l}\text { Gene-disruption } \\
\text { strategies }\end{array}$ & $\begin{array}{l}\text { - Targeted gene deletion for confirmation of proteins/pathways targeted by AFPs } \\
\text { - Deletion libraries to screen for genes associated with sensitivity or resistance to AFPs }\end{array}$ \\
\hline $\begin{array}{l}\text { Transcriptome } \\
\text { analyses }\end{array}$ & $\begin{array}{l}\text { - Microarrays and RNA-seq utilized to identify the mechanism of action of AFPs and } \\
\text { identification of potential secondary effects of treatment }\end{array}$ \\
\hline Proteomics & $\begin{array}{l}\text { - Gel-based methods (e.g. 2D-PAGE) for the characterization of pathways affected by } \\
\text { treatment with AFPs; some limitations associated with constraints in proteome } \\
\text { coverage } \\
\text { - MS-based methods: enable large-scale survey of the proteome for identification of } \\
\text { direct targets of AFPs, identification of potential synergistic drug targets, } \\
\text { characterizing mechanisms of resistance and sensitivity to AFPs }\end{array}$ \\
\hline
\end{tabular}


gene expression led the authors to propose a preliminary model for the mechanism of action of this AFP, whereby nutrient uptake is likely blocked and filamentous growth is suppressed (Morais et al. 2013). The effect of an antimicrobial compound resveratrol on A. flavus was also investigated, using a highly sensitive transcriptomic technique, RNA-seq (Wang et al. 2015). Differential expression of 453 genes was detected in response to resveratrol treatment, including genes involved in mycelial and conidial development, and also secondary metabolite-associated genes. Expression of aflatoxin biosynthetic genes, aflA and aflB, was significantly reduced, corresponding with significantly decreased levels of aflatoxin detected following resveratrol treatment (Wang et al. 2015). Here, transcriptomics not only informed on the possible molecular mechanisms of the antifungal treatment, but also informed on the secondary effects (e.g. altered mycotoxin production) that could prove relevant in application of these agents in food microbiology. Employing time-course experiments has the potential to greatly expand these surveys, informing on the dynamics of the molecular response to antifungal treatments (Lopez-Moya et al. 2016).

Proteomic analyses have provided fundamental information on the systems altered in response to antifungal treatments. Until more recently, the majority of these studies involved gel-based comparative proteomics using SDS-PAGE alone or in combination with isoelectric separation (2DPAGE). 2D-PAGE has been used to evaluate the responses of sensitive fungi to established antifungal therapies, including azoles, polyenes and echinocandins (Gautam et al. 2008; Hoehamer et al. 2010). This technique has also been used to characterize the mechanisms of action of novel antifungal agents (Gautam et al. 2011; Singh et al. 2012; Silva et al. 2013). Gel-based proteomic methods do present some limitations, including difficulties resolving proteins with extremes of $\mathrm{pI}$ or mass, hydrophobic proteins and constraints in the dynamic range visible (Owens et al. 2014). These gel-based techniques can be used in combination with an additional analysis strategy to gain a more comprehensive overview of the systems affected by the antifungal agent. Combining subcellular fractionation with comparative proteomics extends the limits of detection (Komatsu et al. 2011; Cagas et al. 2011; Moloney et al. 2016), while including genomics or alternative proteomic analyses (e.g. gel-free methods) serves to increase sensitivity and validate results (Gautam et al. 2008; Cagas et al. 2011; Gautam et al. 2011; Ene et al. 2012; Delgado et al. 2015b, 2016).

Advances in mass spectrometry (MS)-based proteomic methods have enabled in-depth analysis of the protein levels altered in response to an antifungal challenge. Label-free methods have been utilized to profile the AFPs response within both resistant and sensitive fungi, enabling the identification of resistance mechanisms as well as susceptible targets (Delgado et al. 2015b; Prado et al. 2015; Delgado et al. 2016).
MS has the potential not only just to decipher these modes of action, but also to distinguish between sensitive and resistant strains of a clinically relevant organism using MS-based antifungal susceptibility testing (msAFST) (Vella et al. 2013). In addition to the capacity for proteomics to provide insight into the pathways affected by antifungals, it can also inform on promising targets for antifungal activity. Evaluation of proteomic changes in response to a time-course with the antifungal drug fluconazole revealed potential synergistic drug targets in Cryptococcus gattii following compilation of protein interaction networks (Chong et al. 2012). An MS-based comparative proteomic strategy involving the use of labels has been used to elucidate the mechanism of action of the human AFP histatin 5 (Komatsu et al. 2011). Employing subcellular fractionation to purify mitochondria and two distinct labelling approaches, the authors determined that histatin 5 exerts its activity by decreasing mitochondrial ATP synthesis leading to loss of cellular energy (Komatsu et al. 2011).

Direct identification of antifungal targets is also possible using pull-down strategies combined with MS for identification of protein binding partners. Proteins interacting with the histatin 5 protein described above were detected following coimmunoprecipitation (Co-IP) and a pull-down scheme (Moffa et al. 2015). Among these proteins, one was detected that interfered with histatin 5 activity once complexed, thus identifying potential antagonists of antifungal activity (Moffa et al. 2015). Ghosh et al. (2015) identified potential interactors of the plant AFP mASAL using a different technique involving ligand blots probed with the protein of interest. Collectively, these methods highlight the array of tools that can be utilized to give a system-wide perspective on the molecular targets and biological pathways affected by antifungal agents. These global approaches can facilitate the subsequent focusing of complementary techniques, such as biochemical assays, targeted gene disruption or metabolite analysis.

\section{Mode of action}

The mode of action of these cationic AFPs has been described as multifactorial, but it is hypothesized to involve a direct interaction with anionic phospholipids in the fungal membrane (Lacadena et al. 1995). Thus far, two different mechanisms of action have been elucidated. Some class A AFPs, typically AFP, AFP ${ }_{\mathrm{NN} 5353}$ and AcAFP, bind chitin and are localized to the outer layer of sensitive fungi (Theis et al. 2003, 2005). Then, they alter the cell wall by inhibiting chitin synthesis and permeabilize the cell membrane (Liu et al. 2002; Moreno et al. 2006; Hagen et al. 2007; Skouri-Gargouri et al. 2009). This leads to the disintegration of intracellular structures and cell death (Theis et al. 2005), without relevant morphological changes in sensitive moulds (Theis et al. 2003). Sensitive fungi react to AFP, though 
unsuccessfully, inducing cell wall integrity (CWI) pathway to counteract the AFP (Hagen et al. 2007).

Alternatively, class A PAF interacts with specific components of the plasma membrane, being actively internalized (Oberparleiter et al. 2003). This protein induces severe changes in cell morphology (Kaiserer et al. 2003) that are related to modulation of specific ion channels rather than to chitin or DNA binding (Batta et al. 2009). Class B PgAFP also binds to the outer layer of treated hyphae but, similarly to AFP, leads to no morphological change (Delgado et al. 2015b). Furthermore, class A, B and C AFPs, including PAF, NFAP and PgAFP, lead to reduced chitin biosynthesis at the cell wall and increased levels of intracellular reactive oxygen species (ROS) that trigger programmed cell death (PCD) and apoptosis (Leiter et al. 2005; Galgóczy et al. 2013; Delgado et al. 2015b) (Fig. 1). The onset of apoptotic cell death programs can also be initiated by glutathione/glutathione disulphide redox imbalance (Hegedus et al. 2011). The increased relative abundance of glutathione synthetase and Cys-Gly metallodipeptidase Dug1 in a PgAFP-treated sensitive mould (Delgado et al. 2015b) reveals an unsuccessful reaction to counteract the higher ROS levels, given that these two enzymes would lead to glutathione overproduction. The reduced chitin content associated to this mechanism of action has been related to the fact that PAF fails to activate Pkc/Mpk signalling cascade to induce CWI pathway (Binder et al. 2010b), whereas PgAFP even represses CWI pathway (Delgado et al. 2015b). Therefore, the mechanism of action of AFPs includes alteration or inability to trigger basic defence mechanisms such as CWI pathway, which is aggravated by cell damage due to ROS (Fig. 1). PAF-initiated apoptotic cell death signals may be transmitted by heterotrimeric $G$ protein signalling via cAMP/protein kinase A pathway (Leiter et al. 2005; Binder et al. 2010a; Virágh et al. 2015), where both FadA and GanB G protein $\alpha$-subunits may be involved (Hegedus et al. 2011), as well as $\mathrm{G}$ protein complex $\beta$ subunit $\mathrm{CpcB}$ (Delgado et al. 2015b).

PAF also perturbs $\mathrm{Ca}^{2+}$ homeostasis, increasing the resting level of cytosolic-free $\mathrm{Ca}^{2+}$, and the disruption of $\mathrm{Ca}^{2+}$ signalling may also lead to PCD (Binder et al. 2010a). Interestingly, high external concentrations of $\mathrm{Ca}^{2+}$ or other cations have been shown to reduce the inhibitory effect of AFPs, as will be discussed later.

As it has been shown for PgAFP (Delgado et al. 2015b), some AFPs lead to an increased abundance of proteins involved in energy-hungry ribogenesis and translation processes, whereas key enzymes involved in energy metabolism decrease. These changes could explain the fungistatic effect due to depletion of the cell energy reserves. In addition, the morphological changes caused by AFPs in sensitive fungi (Kaiserer et al. 2003) could be related to the lower abundance of proteins involved in hyphae structure, such as septins and actin (Delgado et al. 2015b).

\section{Mechanisms of resistance}

Different defensive strategies in response to treatment with AFPs have been described for AFPs-producing moulds, naturally resistant fungi or sensitive moulds grown at high $\mathrm{CaCl}_{2}$ concentrations. For some antimicrobial peptides, the resistance has been related to a constitutive lack of electrostatic affinity or receptors for these proteins in cell outer layer (Yeaman and Yount 2003). PgAFP, AFP $_{\mathrm{NN} 5353}$ and PAF do not bind to the cell surface of their respective insensitive producer strain (Oberparleiter et al. 2003; Binder et al. 2011; Delgado et al. 2015b).

In naturally resistant fungi, interactions with AFPs have been reported. In the non-sensitive P. chrysogenum, AFP is internalized and used as a nutritional source, but it binds neither to any specific organelle, nor to the outer layer (Theis et al. 2005). Alternatively, resistant fungi respond against cellular stress caused by AFPs with adaptive mechanisms aimed to maintain the integrity of the cell wall. Echinocandins induce compensatory increases in chitin synthesis, which confers resistance in Candida spp. (Cota et al. 2008; Lee et al. 2012). In the yeast $S$. cerevisiae, the chitin fortification in the presence of AFP is largely dependent on transcriptional stimulation via the calcium/calcineurin/Crzlp pathway (Ouedraogo et al. 2011). Stress signals caused by echinocandins can also be transmitted in S. cerevisiae from the cell surface integrity sensor Wsc1 to the protein kinase $\mathrm{C}$ (PKC) cell integrity signalling pathway, which is controlled by Rho1 protein (ReinosoMartín et al. 2003; Levin 2005). Rho1 binds and activates Pkc, which through Mpk signalling, activates genes involved in cell wall synthesis, resulting in an elevated chitin content (Munro et al. 2007; Delgado et al. 2016).

The successful response of PgAFP-treated Penicillium polonicum is attributed to an efficient CWI pathway activation by Rhol that promotes increased chitin deposition and, as a consequence, lower cell permeability (Delgado et al. 2016) (Fig. 1). Conversely, sensitive A. flavus treated with PgAFP showed lower relative amount of Rhol and chitin deposition (Delgado et al. 2015b). Therefore, chitin deposition mediated by Rho1 seems to play a key role in the sensitivity or resistance of moulds to PgAFP. In addition, $P$. polonicum resistance to PgAFP was weakened by a combined treatment with chitinase, and this combination has been proposed as a means to increase the efficiency of AFPs (Delgado et al. 2016).

On the other hand, the presence of high levels of extracellular cations in the environment provokes a decrease of the antifungal activity of AFPs (Theis et al. 2003; Kaiserer et al. 2003; Martín-Urdiroz et al. 2009; Binder et al. 2010a; Galgóczy et al. 2013). The saturation of the cellular target with cations could potentially be the cause of this reduction in antifungal activity. Given that AFPs have a positive net charge, cations could compete for the putative binding sites at the fungal cell surface (Marx 2004; Martín-Urdiroz et al. 


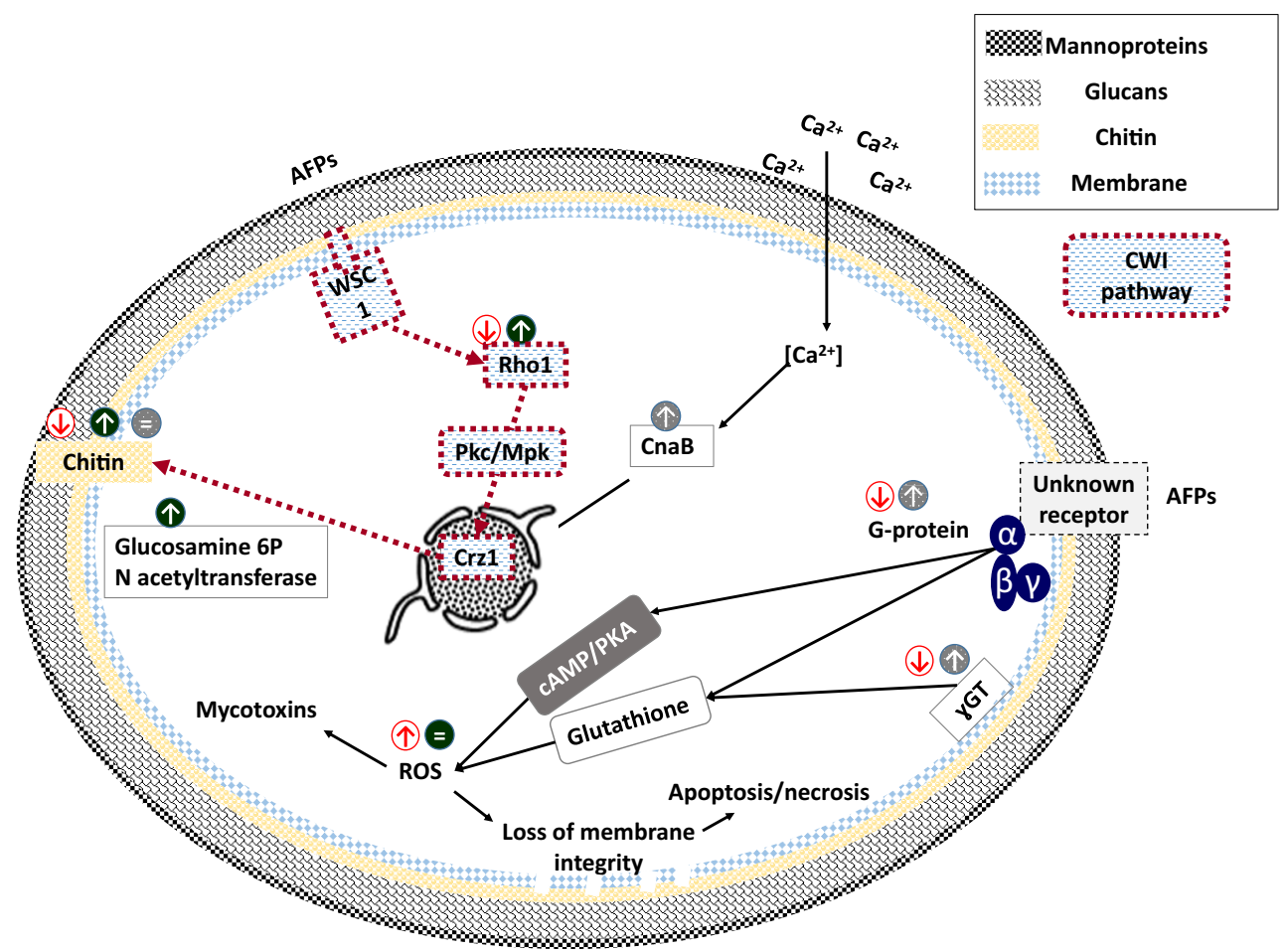

Fig. 1 Role of key proteins in the mechanism of action of AFPs on moulds. Cell wall integrity (CWI) pathway activation: Wsc1 activates Rho1 (Philip and Levin 2001) that plays a key role in the mould response to AFPs (Delgado et al. 2015b; Delgado et al. 2016). Extracellular signals are transmitted via Pkc/Mpk (Binder et al. 2010b), increasing chitin content in the cell wall through Crzl (Ouedraogo et al. 2011). Calcium effect: A high cytosolic calcium concentration activates calcineurin (Thewes 2014). Calcineurin induces post-translational changes through activation of Crzl (Fortwendel et al. 2010), increasing chitin content in the cell wall. Role of G-protein: G-protein transmits apoptotic cell death signals through cAMP/PKA (Leiter et al. 2005) and modulates glutathione pathway (Hegedus et al. 2011), together with GT. cAMP/PKA pathway and glutathione modulate the intracellular ROS levels. High ROS levels may increase mycotoxin production (Jayashree and Subramanyan 2000) and loss of membrane integrity that leads to apoptosis and necrosis phenomena (Leiter et al. 2005; Delgado et al. 2015b). GT gamma glutamyl transpeptidase, $P k c / M p k$ protein kinase $\mathrm{C} /$ mitogen-activated protein kinase, $C W I$ cell wall integrity, $c A M P / P K A$ cyclic adenosine monophosphate/protein kinase A, Rhol small GTP binding protein, $\mathrm{Crz} 1$ calcineurin-responsive zinc finger 1, CnaB calcineurin $\mathrm{Ca}^{2+}$-binding regulatory subunit $\mathrm{CnaB}, W s c l$ wall stress component sensor, ROS reactive oxygen species. ( $\uparrow$ Higher quantity, $\downarrow$ lower quantity, $\bigcirc$ unaltered quantity. $\bigcirc$ variation in a sensitive mould treated with an AFP (Delgado et al. 2015b). Variation in a wild-resistant mould treated with an AFP (Delgado et al. 2016). Variation in a sensitive mould grown in a calcium-enriched medium and treated with an AFP (unpublished data)

also related to resistance of $A$. fumigatus and Candida spp. to echinocandins (Juvvadi et al. 2015; Perlin 2015).

The high calcium levels present in some dry-ripened foods could prevent a successful antifungal effect of AFPs, particularly in cheeses. Given that both LAB (Mandal et al. 2013) and yeasts (Andrade et al. 2014; Núñez et al. 2015) commonly found in ripened foods have shown antifungal capability against toxigenic moulds, the combined action of the AFPs with protective cultures is an alternative that deserves to be investigated.

\section{Impact of AFPs on mycotoxin production}

AFPs have fungistatic effect on sensitive moulds (Theis et al. 2005; Skouri-Gargouri et al. 2009). Retarded growth of treated moulds may result in lower mycotoxin production, as it has been shown for PgAFP on A. flavus at 24-h incubation 
(Delgado et al. 2015b). However, the effect of long-term treatments with AFPs on mycotoxin production is not known. ROS are among the main factors that activate mycotoxin production (Reverberi et al. 2012; Schmidt-Heydt et al. 2014). In fact, oxidative stress is considered a prerequisite for aflatoxin production in toxigenic moulds (Jayashree and Subramanyan 2000). Therefore, mycotoxin production in dry-ripened foods treated with AFPs poses a potential health hazard and deserves to be studied. On the other hand, mycotoxin production can be effectively reduced by antioxidants, such as butylated hydroxyanisole (BHA) (Reverberi et al. 2006), butylated hydroxytoluene (BHT) (Fanelli and Fabbri 1989), $\beta$-glucans from Lentinula edodes (Reverberi et al. 2005) or caffeic acid (Kim et al. 2008). Therefore, antioxidants could be used to minimize mycotoxin production, but their impact on the antifungal effect of AFPs is subject to further investigation.

The use of AFPs may raise additional concerns about public health due to allergic reactions in atopic patients and consumers. On one hand, fungi can cause sensitization and develop asthma, with Aspergillus and Penicillium spp. among the major sources of indoor mould allergies. In fact, allergenic proteins from AFPs-producing species include seven demonstrated allergens from A. niger (Asp n 14, 18, 25, 30, glucoamylase, hemicellulose and pectinase), three from $N$. fischeri (Neo fi 6, transaldolase and $\mathrm{Cu} / \mathrm{Zn}$ superoxide dismutase), two from Penicillium brevicompactum (Pen b 13 and 26), six from P. chrysogenum (Pen ch 13, 18, 20, 31, 33 and 35), ten from Penicillium citrinum (Pen c 1, 2, 3, 13, 18, 19, 22, 24, 30 and 32) and one from Penicillium nalgiovense (Pen na 13) (Allergome 2016). On the other hand, the molecular weight of all characterized allergenic proteins range from 11 to $105 \mathrm{kDa}$, being much larger than AFPs, and the route of exposure described for these allergens is inhalation, with none identified as food allergens so far.

In conclusion, the stability and inhibitory capability of AFPs on toxigenic moulds make these proteins a valuable strategy to prevent mould development and mycotoxin contamination on foods. AFPs-producing moulds, such as P. chrysogenum, have a long record of industrial use and the toxicological information on AFPs is quite encouraging (Szappanos et al. 2005; Palicz et al. 2013). To fully understand the mechanism of action and resistance to AFPs, MS-based proteomic analyses are providing insight into the pathways affected and can inform on new promising targets for antifungal activity. There is still work to be done to find adequate combined treatments for calcium-rich products, but significant steps have been taken to encourage the use of AFPs in dryripened foods.

Acknowledgments Fungal proteomics research at Maynooth University is supported by Science Foundation Ireland Awards to SD: $\mathrm{PI} / 11 / 1188,12 / \mathrm{IP} / 1695$ and 12/RI/2346 (3). This work was supported by the Spanish Ministry of Education and Science, Ministry of Economy and
Competitiveness and FEDER (AGL2010-21623, AGL2013- 45729-P). Josué Delgado was recipient of a FPI grant from the Spanish Ministry of Education and Science (BES-2011-043422 and EEBB-I-13-06900).

\section{Compliance with ethical standards}

Conflict of interest The authors declare that they have no competing interests.

Ethical approval This article does not contain any studies with human participants or animals performed by any of the authors.

\section{References}

Allergome (2016) http://www.allergome.org, Accessed 20 June 2016

Andrade MJ, Thorsen L, Rodríguez A, Córdoba JJ, Jespersen L (2014) Inhibition of ochratoxigenic moulds by Debaryomyces hansenii strains for biopreservation of dry-cured meat products. Int J Food Microbiol 170:70-77. doi:10.1016/j. ijfoodmicro.2013.11.004

Banjara N, Suhr MJ, Hallen-Adams HE (2015) Diversity of yeast and mold species from a variety of cheese types. Curr Microbiol 70:792800. doi:10.1007/s00284-015-0790-1

Batta G, Barna T, Gáspári Z, Sándor S, Kövér KE, Binder U, Sarg B, Kaiserer L, Chhillar AK, Eigentler A, Leiter E, Hegedüs N, Pócsi I, Lindner H, Marx F (2009) Functional aspects of the solution structure and dynamics of PAF-a highly-stable antifungal protein from Penicillium chrysogenum. FEBS J 276:2875-2890. doi:10.1111 jj.1742-4658.2009.07011.x

Bezerra da Rocha ME, Oliveira Freire FDC, Feitosa Maia FE, Florindo Guedes MI, Rondina D (2014) Mycotoxins and their effects on human and animal health. Food Control 36:159-165. doi:10.1016 /j.foodcont.2013.08.021

Binder U, Bencina M, Eigentler A, Meyer V, Marx F (2011) The Aspergillus giganteus antifungal protein $\mathrm{AFP}_{\mathrm{NN} 5353}$ activates the cell wall integrity pathway and perturbs calcium homeostasis. BMC Microbiol 11:209. doi:10.1186/1471-2180-11209

Binder U, Chu M, Read ND, Marx F (2010a) The antifungal activity of the Penicillium chrysogenum protein PAF disrupts calcium homeostasis in Neurospora crassa. Eukaryot Cell 9:1374-1382. doi:10.1128/EC.00050-10

Binder U, Oberparleiter C, Meyer V, Marx F (2010b) The antifungal protein PAF interferes with PKC/MPK and cAMP/PKA signalling of Aspergillus nidulans. Mol Microbiol 75:294-307. doi:10.1111 j.1365-2958.2009.06936.x

Bobolea I, Barranco P, Jurado-Palomo J, Pedrosa M, Quirce S (2009) Allergy to dry fermented sausage. J Investig Allergol Clin Immunol 19:324-325. doi:10.1016/j.jaci.2008.12.961

Bruna JM, Hierro EM, De La Hoz L, Mottram DS, Fernández M, Ordóñez JA (2003) Changes in selected biochemical and sensory parameters as affected by the superficial inoculation of Penicillium camemberti on dry fermented sausages. Int J Food Microbiol 85: 111-125. doi:10.1016/S0168-1605(02)00505-6

Cagas SE, Jain MR, Li H, Perlin DS (2011) Profiling the Aspergillus fumigatus proteome in response to caspofungin. Antimicrob Agents Chemother 55:146-154. doi:10.1128/AAC.00884-10

Chong HS, Campbell L, Padula MP, Hill C, Harry E, Li SS, Wilkins MR, Herbert B, Carter D (2012) Time-course proteome analysis reveals the dynamic response of Cryptococcus gattii cells to fluconazole. PLoS One 7:1-10. doi:10.1371/journal.pone.0042835 
Campos-Olivas R, Bruix M, Santoro J, Lacadena J, Martinez del Pozo A, Gavilanes JG, Rico M (1995) NMR solution structure of the antifungal protein from Aspergillus giganteus: evidence for cysteine pairing isomerism. Biochemistry 34:3009-3021. doi:10.1021 /bi00009a032

Chen Z, Ao J, Yang W, Jiao L, Zheng T, Chen X (2013) Purification and characterization of a novel antifungal protein secreted by Penicillium chrysogenum from an Arctic sediment. Appl Microbiol Biotechnol 97:10381-10390. doi:10.1007/s00253-0134800-6

Colot HV, Park G, Turner GE, Ringelberg C, Crew CM, Litvinkova L, Weiss RL, Borkovich KA, Dunlap JC (2006) A high-throughput gene knockout procedure for Neurospora reveals functions for multiple transcription factors. Proc Natl Acad Sci U S A 103:1035210357. doi:10.1073/pnas.0601456103

Cota JM, Grabinski JL, Talbert RL, Burgess DS, Rogers PD, Edlind TD, Wiederhold NP (2008) Increases in SLT2 expression and chitin content are associated with incomplete killing of Candida glabrata by caspofungin. Antimicrob Agents Chemother 52:1144-1146. doi:10.1128/AAC.01542-07

Delgado J, Acosta R, Rodríguez-Martín A, Bermúdez E, Núñez F, Asensio MA (2015a) Growth inhibition and stability of PgAFP from Penicillium chrysogenum against fungi common on dry-ripened meat products. Int J Food Microbiol 205:23-29. doi:10.1016/j. ijfoodmicro.2015.03.029

Delgado J, Owens RA, Doyle S, Asensio MA, Núñez F (2015b) Impact of the antifungal protein PgAFP from Penicillium chrysogenum on the protein profile in Aspergillus flavus. Appl Microbiol Biotechnol 99:8701-8715. doi:10.1007 /s00253-015-6731-x

Delgado J, Owens RA, Doyle S, Asensio MA, Núñez F (2016) Increased chitin biosynthesis contributes to the resistance of Penicillium polonicum against the antifungal protein PgAFP. Appl Microbiol Biotechnol 100:371-383. doi:10.1007/s00253015-7020-4

Emri T, Majoros L, Tóth V, Pócsi I (2013) Echinocandins: production and applications. Appl Microbiol Biotechnol 97:3267-3284. doi:10.1007/s00253-013-4761-9

Ene IV, Heilmann CJ, Sorgo AG, Walker LA, De Koster CG, Munro CA, Klis FM, Brown AJP (2012) Carbon sourceinduced reprogramming of the cell wall proteome and secretome modulates the adherence and drug resistance of the fungal pathogen Candida albicans. Proteomics 12:31643179. doi:10.1002/pmic. 201200228

Fanelli C, Fabbri AA (1989) Relationship between lipids and aflatoxin biosynthesis. Mycopathologia 107:115-120. doi:10.1007 /BF00707547

Fortwendel JR, Juvvadi PR, Perfect BZ, Rogg LE, Perfect JR, Steinbach WJ (2010) Transcriptional regulation of chitin synthases by calcineurin controls paradoxical growth of Aspergillus fumigatus in response to caspofungin. Antimicrob Agents Chemother 54:15551563. doi:10.1128/AAC.00854-09

Galgóczy L, Kovács L, Karácsony Z, Virágh M, Hamari Z, Vágvölgyi C (2013) Investigation of the antimicrobial effect of Neosartorya fischeri antifungal protein (NFAP) after heterologous expression in Aspergillus nidulans. Microbiology 159:411-419. doi:10.1099 /mic.0.061119-0

Galgóczy L, Papp T, Pócsi I, Hegedus N, Vágvölgyi C (2008) In vitro activity of Penicillium chrysogenum antifungal protein (PAF) and its combination with fluconazole against different dermatophytes. Antonie Van Leeuwenhoek 94:463-470. doi:10.1007/s10482-0089263-x

Garrigues S, Gandía M, Marcos JF (2015) Occurrence and function of fungal antifungal proteins: a case study of the citrus postharvest pathogen Penicillium digitatum. Appl Microbiol Biotechnol 100: 2243-2256. doi:10.1007/s00253-015-7110-3
Gautam P, Shankar J, Madan T, Sirdeshmukh R, Sundaram CS, Gade WN, Basir SF, Sarma PU (2008) Proteomic and transcriptomic analysis of Aspergillus fumigatus on exposure to amphotericin B. Antimicrob Agents Chemother 52:4220-4227. doi:10.1128 /AAC.01431-07

Gautam P, Upadhyay SK, Hassan W, Madan T, Sirdeshmukh R, Sundaram CS, Gade WN, Basir SF, Singh Y, Sarma PU (2011) Transcriptomic and proteomic profile of Aspergillus fumigatus on exposure to artemisinin. Mycopathologia 172:331-346. doi:10.1007/s11046-011-9445-3

Geisen R (2000) P. nalgiovense carries a gene which is homologous to the paf gene of $P$. chrysogenum which codes for an antifungal peptide. Int J Food Microbiol 62:95-101. doi:10.1016/S0168-1605(00 )00367-6

Ghosh P, Roy A, Hess D, Ghosh A, Das S (2015) Deciphering the mode of action of a mutant Allium sativum leaf agglutinin (mASAL), a potent antifungal protein on Rhizoctonia solani. BMC Microbiol 15: 237. doi:10.1186/s12866-015-0549-

González-de-Olano D, Gandolfo-Cano M, González-Mancebo E, Meléndez-Baltanás A, Juárez-Guerrero R, Bartolomé B (2012) Different patterns of sensitization in allergy to dry fermented sausage. J Investig Allergol Clin Immunol 22:152-153

Gun Lee D, Shin SY, Maeng CY, Jin ZZ, Kim KL, Hahm KS (1999) Isolation and characterization of a novel antifungal peptide from Aspergillus niger. Biochem Biophys Res Commun s 263:646-651. doi:10.1006/bbrc.1999.1428

Hagen S, Marx F, Ram AF, Meyer V (2007) The antifungal protein AFP from Aspergillus giganteus inhibits chitin synthesis in sensitive fungi. Appl Environ Microbiol 73:2128-2134. doi:10.1128 /AEM.02497-06

Hajji M, Jellouli K, Hmidet N, Balti R, Sellami-Kamoun A, Nasri M (2010) A highly thermostable antimicrobial peptide from Aspergillus clavatus ES1: biochemical and molecular characterization. J Ind Microbiol Biotechnol 37:805-813. doi:10.1007/s10295010-0725-6

Hegedus N, Leiter E, Kovács B, Tomori V, Kwon N-J, Emri T, Marx F, Batta G, Csernoch L, Haas H, Yu J-H, Pócsi I (2011) The small molecular mass antifungal protein of Penicillium chrysogenum-a mechanism of action oriented review. J Basic Microbiol 51:561571. doi:10.1002/jobm.201100041

Hegedüs N, Marx F (2013) Antifungal proteins: more than antimicrobials? Fungal Biol Rev 26:132-145. doi:10.1016/j.fbr.2012.07.002

Hoehamer CF, Cummings ED, Hilliard GM, Rogers PD (2010) Changes in the proteome of Candida albicans in response to azole, polyene, and echinocandin antifungal agents. Antimicrob Agents Chemother 54:1655-1664. doi:10.1128/AAC.00756-09

Hughes MC, Kerry JP, Arendt EK, Kenneally PM, McSweeney PLH, O'Neill EE (2002) Characterization of proteolysis during the ripening of semi-dry fermented sausages. Meat Sci 62:205-216. doi:10.1016/S0309-1740(01)00248-0

Jayashree T, Subramanyan C (2000) Oxidative stress as a prerequisite for aflatoxin production by Aspergillus parasiticus. Free Radic Biol Med 29:981-985

Juvvadi PR, Muñoz A, Lamoth F, Soderblom EJ, Moseley MA, Read ND, Steinbach WJ (2015) Calcium-mediated induction of paradoxical growth following caspofungin treatment is associated with calcineurin activation and phosphorylation in Aspergillus fumigatus. Antimicrob Agents Chemother 59:4946-4955. doi:10.1128 /AAC.00263-15

Kaiserer L, Oberparleiter C, Weiler-Görz R, Burgstaller W, Leiter E, Marx F (2003) Characterization of the Penicillium chrysogenum antifungal protein PAF. Arch Microbiol 180:204-210. doi:10.1007 /s00203-003-0578-8

Kim JH, Yu J, Mahoney N, Chan KL, Molyneux RJ, Varga J, Bhatnagar D, Cleveland TE, Nierman WC, Campbell BC (2008) Elucidation of the functional genomics of antioxidant-based inhibition of aflatoxin 
biosynthesis. Int J Food Microbiol 122:49-60. doi:10.1016/j. ijfoodmicro.2007.11.058

Komatsu T, Salih E, Helmerhorst EJ, Offner GD, Oppenheim FG (2011) Influence of histatin 5 on Candida albicans mitochondrial protein expression assessed by quantitative mass spectrometry. J Proteome Res 10:646-655. doi:10.1021/pr100861k

Kovács L, Virágh M, Takó M PT, Vágvölgyi C, Galgóczy L (2011) Isolation and characterization of Neosartorya fischeri antifungal protein (NFAP). Peptides 32:1724-1731. doi:10.1016/j.peptides. 2011.06.022

Lacadena J, Martínez Del Pozo A, Gasset M, Patiño B, Campos-Olivas R, Vázquez C, Martínez-Ruiz A, Mancheño J, Oñaderra M, Gavilanes JG (1995) Characterization of the antifungal protein secreted by the mould Aspergillus giganteus. Arch Biochem Biophys 324:273-281

Lee KK, MacCallum DM, Jacobsen MD, Walker LA, Odds FC, Gow NAR, Munro CA (2012) Elevated cell wall chitin in Candida albicans confers echinocandin resistance in vivo. Antimicrob Agents Chemother 56:208-217. doi:10.1128/AAC.00683-11

Leiter É, Marx F, Pusztahelyi T, Haas H, Pócsi I (2004) Penicillium chrysogenum glucose oxidase - a study on its antifungal effects. J Appl Microbiol 97:1201-1209. doi:10.1111/j.13652672.2004.02423.x

Leiter É, Szappanos H, Oberparleiter C, Kaiserer L, Csernoch L, Pusztahelyi T, Emri T, Pócsi I, Salvenmoser W, Marx F (2005) Antifungal protein PAF severely affects the integrity of the plasma membrane of Aspergillus nidulans and induces an apoptosis-like phenotype. Antimicrob Agents Chemother 49:2445-2453. doi:10.1128/AAC.49.6.2445

Levin DE (2005) Cell wall integrity signaling in Saccharomyces cerevisiae. Microbiol Mol Biol Rev 69:262-291. doi:10.1128 /MMBR.69.2.262

Liu R, Chen L, Jiang Y, Zhou Z, Zou G (2015) Efficient genome editing in filamentous fungus Trichoderma reesei using the CRISPR/Cas9 system. Cell Discov 1:15007. doi:10.1038/celldisc.2015.7

Liu R, Huang H, Yang Q, Liu W-Y (2002) Purification of alpha-sarcin and an antifungal protein from mold (Aspergillus giganteus) by chitin affinity chromatography. Protein Expr Purif 25:50-58. doi:10.1006/prep.2001.1608

Liu X, Wang J, Gou P, Mao C, Zhu ZR, Li H (2007) In vitro inhibition of postharvest pathogens of fruit and control of gray mold of strawberry and green mold of citrus by aureobasidin a. Int J Food Microbiol 119:223-229. doi:10.1016/j.ijfoodmicro.2007.07.054

Lopez-Moya F, Kowbel D, Nueda MJ, Palma-Guerrero J, Glass NL, Lopez-Llorca LV (2016) Neurospora crassa transcriptomics reveals oxidative stress and plasma membrane homeostasis biology genes as key targets in response to chitosan. Mol BioSyst 12:391-403. doi:10.1039/C5MB00649J

Mandal V, Sen SK, Mandal NC (2013) Production and partial characterisation of an inducer-dependent novel antifungal compound(s) by Pediococcus acidilactici LAB 5. J Sci Food Agric 93:2445-2453. doi:10.1002/jsfa.6055

Martín A, Córdoba JJ, Núñez F, Benito MJ, Asensio MA (2006) Contribution of a selected fungal population to proteolysis on drycured ham. Int J Food Microbiol 110:8-18. doi:10.1016/j. ijfoodmicro.2003.12.018

Martín-Urdiroz M, Martínez-Rocha AL, di Pietro A, Martínez-del-Pozo Á, Roncero MIG (2009) Differential toxicity of antifungal protein AFP against mutants of Fusarium oxysporum. Int Microbiol 12: 115-121. doi:10.2436/20.1501.01.88

Marvisi M, Balzarini L, Mancini C, Mouzakiti P (2012) A new type of hypersensitivity pneumonitis: salami brusher's disease. Monaldi Arch Chest Dis-Pulm Ser 77:35-37

Marx F (2004) Small, basic antifungal proteins secreted from filamentous ascomycetes: a comparative study regarding expression, structure, function and potential application. Appl Microbiol Biotechnol 65: 133-142. doi:10.1007/s00253-004-1600-z
Marx F, Binder U, Leiter E, Pócsi I (2008) The Penicillium chrysogenum antifungal protein PAF, a promising tool for the development of new antifungal therapies and fungal cell biology studies. Cell Mol Life Sci 65:445-454. doi:10.1007/s00018-007-7364-8

Marx F, Haas H, Reindl M, Stöffler G, Lottspeich F, Redl B (1995) Cloning, structural organization and regulation of expression of the Penicillium chrysogenum paf gene encoding an abundantly secreted protein with antifungal activity. Gene 167:167-171

Moffa EB, Machado MAAM, Mussi MCM, Xiao Y, Garrido SS, Giampaolo ET, Siqueira WL (2015) In vitro identification of histatin 5 salivary complexes. PLoS One 10:1-13. doi:10.1371/journal. pone. 0142517

Moloney NM, Owens RA, Meleady P, Henry M, Dolan SK, Mulvihill E, Clynes M, Doyle S (2016) The iron-responsive microsomal proteome of Aspergillus fumigatus. J Proteomics 136:99-111. doi:10.1016/j.jprot.2015.12.025

Morais JKS, Bader O, Weig M, Oliveira JTA, Arantes MR, Gomes VM, Da Cunha M, Oliveira HD, Sousa DOB, Lourencao AL, Vasconcelos IM (2013) Soybean toxin (SBTX) impairs fungal growth by interfering with molecular transport, carbohydrate/ amino acid metabolism and drug/stress responses. PLoS One. doi:10.1371/journal.pone.0070425

Moreno AB, Martínez Del Pozo A, San Segundo B, Martínez Del Pozo Á, San Segundo B (2006) Antifungal mechanism of the Aspergillus giganteus AFP against the rice blast fungus Magnaporthe grisea. Appl Microbiol Biotechnol 72:883-895. doi:10.1007/s00253-0060362-1

Munro CA, Selvaggini S, De Bruijn I, Walker L, Lenardon MD, Gerssen B, Milne S, Brown AJP, Gow NAR (2007) The PKC, HOG and $\mathrm{Ca}^{2+}$ signalling pathways co-ordinately regulate chitin synthesis in Candida albicans. Mol Microbiol 63:1399-1413. doi:10.1111 j.1365-2958.2007.05588.x

Nakaya K, Omata K, Okahashi I, Nakamura Y, Kolkenbrock H, Ulbrich N (1990) Amino acid sequence and disulfide bridges of an antifungal protein isolated from Aspergillus giganteus. Eur J Biochem 193:31-38

Nødvig CS, Nielsen JB, Kogle ME, Mortensen UH (2015) A CRISPRCas9 system for genetic engineering of filamentous fungi. PLoS One 10:1-18. doi:10.1371/journal.pone.0133085

Núñez F, Lara MS, Peromingo B, Delgado J, Sanchez-Montero L, Andrade MJ (2015) Selection and evaluation of Debaryomyces hansenii isolates as potential bioprotective agents against toxigenic penicillia in dry-fermented sausages. Food Microbiol 46:114-120. doi:10.1016/j.fm.2014.07.019

Oberparleiter C, Kaiserer L, Haas H, Ladurner P, Andratsch M, Marx F (2003) Active internalization of the Penicillium chrysogenum antifungal protein PAF in sensitive aspergilli. Antimicrob Agents Chemother 47:3598-3601. doi:10.1128/AAC.47.11.3598

Ouedraogo JP, Hagen S, Spielvogel A, Engelhardt S, Meyer V (2011) Survival strategies of yeast and filamentous fungi against the antifungal protein AFP. J Biol Chem 286:13859-13868. doi:10.1074 jjbc.M110.203588

Owens RA, Hammel S, Sheridan KJ, Jones GW, Doyle S (2014) A proteomic approach to investigating gene cluster expression and secondary metabolite functionality in Aspergillus fumigatus. PLoS One 9:e106942. doi:10.1371/journal.pone.0106942

Palicz Z, Jenes Á, Gáll T, Miszti-Blasius K, Kollár S, Kovács I, Emri M, Márián T, Leiter É, Pócsi I, Csosz É, Kalló G, Hegedus C, Virág L, Csernoch L, Szentesi P (2013) In vivo application of a small molecular weight antifungal protein of Penicillium chrysogenum (PAF). Toxicol Appl Pharmacol 269:8-16. doi:10.1016/j.taap.2013.02.014

Park G, Colot HV, Collopy PD, Krystofova S, Crew C, Ringelberg C, Litvinkova L, Altamirano L, Li L, Curilla S, Wang W, Gorrochotegui-Escalante N, Dunlap JC, Borkovich KA (2011) High-throughput production of gene replacement mutants in Neurospora crassa. Methods Mol Biol 722:179-189. doi:10.1007 1978-1-61779-040-9 
Perlin DS (2015) Mechanisms of echinocandin antifungal drug resistance. Ann N Y Acad Sci 1354:1-11. doi:10.1111/nyas.12831

Philip B, Levin DE (2001) Wsc1 and Mid2 are cell surface sensors for Cell Wall integrity signaling that act through Rom2, a guanine nucleotide exchange factor for Rho1. Mol Cell Biol 21:271-280. doi:10.1128/MCB.21.1.271

Prado RS, Bailão AM, Silva LC, de Oliveira CMA, Marques MF, Silva LP, Silveira-Lacerda EP, Lima AP, Soares CM, Pereira M (2015) Proteomic profile response of Paracoccidioides lutzii to the antifungal argentilactone. Front Microbiol 6:1-14. doi:10.3389 /fmicb.2015.00616

Reinoso-Martín C, Schu C, Schuetzer-muehlbauer M, Kuchler K, Schüller C (2003) The yeast protein kinase $C$ cell integrity pathway mediates tolerance to the antifungal drug caspofungin through activation of sit $2 p$ mitogen-activated protein kinase signaling. Eukaryot Cell 2:1200-1210. doi:10.1128/EC.2.6.1200

Reverberi M, Fabbri AA, Zjalic S, Ricelli A, Punelli F, Fanelli C (2005) Antioxidant enzymes stimulation in Aspergillus parasiticus by Lentinula edodes inhibits aflatoxin production. Appl Microbiol Biotechnol 69:207-215. doi:10.1007/s00253-005-1979-1

Reverberi M, Punelli M, Smith CA, Zjalic S, Scarpari M, Scala V, Cardinali G, Aspite N, Pinzari F, Payne GA, Fabbri AA, Fanelli C (2012) How peroxisomes affect aflatoxin biosynthesis in Aspergillus flavus. PLoS One 7:e48097. doi:10.1371/journal. pone.0048097

Reverberi M, Zjalic S, Ricelli A, Fabbri A, Fanelli C (2006) Oxidant/ antioxidant balance in Aspergillus parasiticus affects aflatoxin biosynthesis. Mycotoxin Res 22:39-47. doi:10.1007/BF02954556

Rodríguez M, Núñez F, Córdoba JJ, Bermúdez ME, Asensio MA (1998) Evaluation of proteolytic activity of micro-organisms isolated from dry cured ham. J Appl Microbiol 85:905-912

Rodríguez-Martín A, Acosta R, Liddell S, Núñez F, Benito MJ, Asensio MA (2010a) Characterization of the novel antifungal protein PgAFP and the encoding gene of Penicillium chrysogenum. Peptides 31: 541-547. doi:10.1016/j.peptides.2009.11.002

Rodríguez-Martín A, Acosta R, Liddell S, Núñez F, Benito MJ, Asensio MA (2010b) Characterization of the novel antifungal chitosanase $\mathrm{PgChP}$ and the encoding gene from Penicillium chrysogenum. Appl Microbiol Biotechnol 88:519-528. doi:10.1007/s00253-0102767-0

Schmidt-Heydt M, Stoll D, Schütz P, Geisen R (2014) Oxidative stress induces the biosynthesis of citrinin by Penicillium verrucosum at the expense of ochratoxin. Int J Food Microbiol 192:1-6. doi:10.1016/j. ijfoodmicro.2014.09.008

Seibold M, Wolschann P, Bodevin S, Olsen O (2011) Properties of the bubble protein, a defensin and an abundant component of a fungal exudate. Peptides 32:1989-1995. doi:10.1016/j. peptides.2011.08.022

Selitrennikoff CP (2001) Antifungal proteins. Appl Environ Microbiol 67:2883-2894. doi:10.1128/AEM.67.7.2883

Silva FAC, Pirovani CP, Menezes S, Pungartnik C, Santiago AS (2013) Proteomic response of Moniliophthora perniciosa exposed to pathogenesis-related protein-10 from Theobroma cacao. Genet Mol Res 12:4855-4868

Singh S, Gupta S, Singh B, Sharma SK, Gupta VK, Sharma GL (2012) Proteomic characterization of Aspergillus fumigatus treated with an antifungal coumarin for identification of novel target molecules of key pathways. J Proteome Res 11:3259-3268. doi:10.1021 /pr300006j

Skouri-Gargouri H, Ben Ali M, Gargouri A (2009) Molecular cloning, structural analysis and modelling of the AcAFP antifungal peptide from Aspergillus clavatus. Peptides 30:1798-1804. doi:10.1016/j. peptides.2009.06.034
Skouri-Gargouri H, Gargouri A (2008) First isolation of a novel thermostable antifungal peptide secreted by Aspergillus clavatus. Peptides 29:1871-1877. doi:10.1016/j.peptides.2008.07.005

Sousa MJ, Ardö Y, McSweeney PLH (2001) Advances in the study of proteolysis during cheese ripening. Int Dairy J 11:327-345. doi:10.1016/S0958-6946(01)00062-0

Swan JRM, Crook B (1998) Airborne microorganisms associated with grain handling. Ann Agric Env Med 5:7-15

Szappanos H, Szigeti GP, Pál B, Rusznák Z, Szucs G, Rajnavölgyi E, Balla J, Balla G, Nagy E, Leiter E, Pócsi I, Marx F, Csernoch L (2005) The Penicillium chrysogenum-derived antifungal peptide shows no toxic effects on mammalian cells in the intended therapeutic concentration. Naunyn Schmiedeberg's Arch Pharmacol 371: 122-132. doi:10.1007/s00210-004-1013-7

Theis T, Marx F, Salvenmoser W, Stahl U, Meyer V (2005) New insights into the target site and mode of action of the antifungal protein of Aspergillus giganteus. Res Microbiol 156:47-56. doi:10.1016/j. resmic.2004.08.006

Theis T, Stahl U (2004) Antifungal proteins: targets, mechanisms and prospective applications. Cell Mol Life Sci : CMLS 61:437-455. doi:10.1007/s00018-003-3231-4

Theis T, Wedde M, Meyer V, Stahl U (2003) The antifungal protein from Aspergillus giganteus causes membrane permeabilization. Antimicrob Agents Chemother 47:588-593. doi:10.1128 /AAC.47.2.588-593.2003

Thewes S (2014) Calcineurin-Crz1 signaling in lower eukaryotes. Eukaryot Cell 13:694-705. doi:10.1128/EC.00038-14

Tu CY, Chen YP, Yu MC, Hwang E, Wu DY, Liaw LL (2016) Characterization and expression of the antifungal protein from Monascus pilosus and its distribution among various Monascus species. J Biosci Bioeng 122:27-33. doi:10.1016/j.jbiosc.2015.12.009

van der Weerden NL, Anderson MA (2013) Plant defensins: common fold, multiple functions. Fungal Biol Rev 26:121-131. doi:10.1016 /j.fbr.2012.08.004

Vella A, De Carolis E, Vaccaro L, Posteraro P, Perlin DS, Kostrzewa M, Posteraro B, Sanguinetti M (2013) Rapid antifungal susceptibility testing by matrix-assisted laser desorption ionization-time of flight mass spectrometry analysis. J Clin Microbiol 51:2964-2969. doi:10.1128/JCM.00903-13

Virágh M, Marton A, Vizler C, Tóth L, Vágvölgyi C, Marx F, Galgóczy L (2015) Insight into the antifungal mechanism of Neosartorya fischeri antifungal protein. Protein Cell 6:518-528. doi:10.1007 /s13238-015-0167-z

Vriens K, Cammue BPA, Thevissen K (2014) Antifungal plant defensins: mechanisms of action and production. Molecules 19:12280-12303. doi:10.3390/molecules190812280

Wang H, Lei Y, Yan L, Cheng K, Dai X, Wan L, Guo W, Cheng L, Liao B (2015) Deep sequencing analysis of transcriptomes in Aspergillus flavus in response to resveratrol. BMC Microbiol 15:182. doi:10.1186/s12866-015-0513-6

Wen C, Guo W, Chen X (2014) Purification and identification of a novel antifungal protein secreted by Penicillium citrinum from the Southwest Indian Ocean. J Microbiol Biotechnol 24:1337-1345

Yan J, Yuan S, Jiang L, Ye X, Ng TB, Wu Z (2015) Plant antifungal proteins and their applications in agriculture. Appl Microbiol Biotechnol 99:4961-4981. doi:10.1007/s00253-015-6654-6

Yeaman MR, Yount NY (2003) Mechanisms of antimicrobial peptide action and resistance. Pharmacol Rev 55:27-55. doi:10.1124 pr.55.1.2.27

Zhu R, Feussner K, Wu T, Yan F, Karlovsky P, Zheng X (2015) Detoxification of mycotoxin patulin by the yeast Rhodosporidium paludigenum. Food Chem 179:1-5. doi:10.1016/j. foodchem.2015.01.066 